\title{
Obituary
}

\section{Dr. Ernst Hartert}

$\mathrm{T}^{\mathrm{H}}$ HE whole ornithological world will deplore the death of Dr. Ernst Hartert, which took place at Berlin on November 10, shortly after his seventy-fourth birthday. His loss will be particularly severely felt in Great Britain, where he had done his best work, for he had spent the greater part of his life as director of Lord Rothschild's Museum at Tring.

Hartert was a master of his subject. Not only had he a wider knowledge of the birds of the world than probably any other ornithologist, but also his knowledge of those of certain regions was extremely intimate. For many years we enjoyed the advantage of having this great authority in our midst, and his influence on systematic ornithology was immense. He was the apostle of an orderly system based on a thorough-going belief in geographical forms or sub-species as a part of the natural scheme, and the grouping of these by means of a trinomial nomenclature governed by rules of strict priority. His views met with great opposition at first from most of the older and most influential ornithologists of the time, but gradually the system he adopted and perfected began to be used, until to-day it has become universal.

Hartert was born in Germany and spent much of his youth in East Prussia; although he lived in England from 1892 until 1930, and became naturalised soon after his arrival, he always retained his natural German characteristics, which were not, however, at all of the aggressive type usually associated with Prussia. That a foreigner should have achieved so great a success in so heretical a mission in Great Britain, where the Ornithologists' Union is the oldest in the world, tells more than any words of the strength of character, the tenacity of purpose and the soundness of judgment Hartert brought to his task, and these traits were reinforced by intense sincerity and keenness, a constant readiness to help and advise, as well as by an original and very likeable personality.

This achievement was intimately connected with the two great works of Hartert's life. First, the building up of the collection of birds at Tring, and secondly, his intense study of the birds of the Palæarctic region. These tasks could only have been accomplished by untiring zeal and constant work. To build up such a collection there must be money, but money alone is of little use : there must be continuous and persistent search and organisation year in and year out to find out what gaps must be filled and how it shall be done. It was this constant adding of birds not represented in the collection which enabled Hartert, so ably backed up by Lord Rothschild, to bring together a collection which was not only enormous in point of numbers - there were 280,000 skins - but was well collected and representative of the birds of the world.

This wonderful collection, which was especially complete in Palæarctic birds, gave Hartert the main material for his great work "Die Vögel der paläarktischen Fauna", publication of which commenced in 1903, was suspended from October 1914 to March 1920, and was completed in 1922. In 1933 a "Nachtrag" was published, while in 1932 was commenced an "Ergänzungsband" of which two parts have been issued. These supplements are extremely valuable to specialists, but the original work will always stand out as a most complete and perfect systematic account of the birds of this great region.

In 1912 was published the "Handlist of British Birds", in which Hartert was responsible for the classification and nomenclature employed, and it was this book, even more than his great Palæarctic work, that brought to a head the intense opposition to his system in Great Britain. Later, when the "Practical Handbook of British Birds" appeared (1919-24), with Hartert as specialist in the same subjects, the system had become generally adopted.

In his early days, Hartert travelled extensively, making expeditions in search of birds to northern Nigeria, the East Indies, the West. Indies and Venezuela, as well as to Morocco, the Canaries and Madeira. Later, in company at times with Lord Rothschild, he made many expeditions to North-West Africa. He knew more about the birds of "Africa minor" at first hand and by subsequent study than anyone, and the Tring Museum became celebrated for its very complete series of birds from that region. He was a splendid collector and made beautiful skins, every one of which had its scientific value.

Hartert's first work in England was writing the account of the swifts and goatsuckers for the sixteenth volume of the "Catalogue of Birds in the British Museum". He contributed to other standard works and wrote a large number of valuable technical papers which appeared in various ornithological journals, and notably Novitates Zoologicae, the organ of the Tring Museum. He described hundreds of new birds from all over the world and his name has been perpetuated in numbers of birds described by others.

Mention must be made of Hartert's fine attitude during the War, when his dearest friends in two nations were opposed, and his only son, having joined the British Army, was killed in action. It was he who was chiefly instrumental in reviving after the War the International Ornithological Congress, and it was fitting that he should be president of the first post-War Congress at Copenhagen in 1926.

On his seventieth birthday, October 29, 1929, a "Festschrift" was published in Germany in Dr. Hartert's honour, and the British Ornithologists' 
Union presented him with the Godman-Salvin gold medal. Shortly afterwards he went to live at Berlin, and here he had a room in the Museum where he continued to work at birds until within two or three days of his death.

The retirement of Hartert in 1930, the sale of the great Tring collection to New York in 1932, and now the death of this great figure in the bird world, close an important chapter in the history of ornithology.

H. F. W.

\section{Sir R. Forsyth Scote}

WE regret to announce that Sir Robert Forsyth Scott, master of St. John's College, Cambridge, died on November 18, at the age of eighty-four years. He had for some time been in failing health but he retained his keen interest in the affairs of the College and was glad to see his friends until a few days before his death. Only a few weeks before, he had completed fifty years in the service of the College, twenty-five years as senior bursar and twenty-five years as master. To this service he gave himself without reserve. His acute mind, with a combination of mathematical and legal training, added to his knowledge of and sympathy with men, made that service invaluable to the College during a long period of difficult finance.

Scott was born at Leith on July 28, 1849, son of the Rev. George Scott, minister of the Established Church of Scotland at Dairsie, Fife. $\mathrm{He}$ was educated at the Edinburgh High School and afterwards in Stuttgart. After spending a time as a student at King's College, London, he went into residence at St. John's College, Cambridge, with an entrance exhibition in mathematics. A fellow student was William Burnside, who however migrated from St. John's to Pembroke-it is said to do more work. In the Tripos of 1875 , Scott was fourth wrangler, Burnside being bracketed with Chrystal just above him : three Scots. Remaining in residence for two more years, Scott maintained his interest in mathematics and at the same time continued to row in the College boats; his interest in the success of the College on the river, begun then, he continued throughout his life.

In 1876 Scott was elected to a MacMahon law studentship, and in 1877 to a fellowship. For two years after that he held an assistant mathematical mastership at Christ's Hospital, but he had chosen the law as a profession and in 1880 he was called to the Bar by Lincoln's Inn. The end of his active career as a mathematician was marked by the publication in that year of his "Theory of Determinants", one of the earliest of the advanced mathematical treatises published by the Cambridge University Press. Written in a fresh, unpretentious style, this book must be counted a great achievement in the state of mathematical teaching in Cambridge at that time. It has remained until the present day, in the form of the second edition revised by G. B. Mathews, as the only substantial work on the subject in English, ana present-day developments in mathematics are causing its value to be appreciated again. From 1880 until 1884 he was a member of the Council of the London Mathematical Society. Glaisher is remembered to have said that Scott was a great help to the Society in a time of considerable difficulty.

After practising in Lincoln's Inn for three years, Scott, somewhat reluctantly, abandoned the legal profession to accept the invitation of his College to become senior bursar. But, like everything else he had attempted, he made an outstanding success of his new work, and laid well the foundations of prosperity for the College. At the same time he entered with great interest into undergraduate life. It is said by one who knew him well that in 1888 he was one of the most effective and yet popular of proctors. His breakfasts given to the College boats when in training will not be forgotten by those who partook of them. His gift for public affairs was turned to good account as a member of the Council of the Senate and of the Cambridge Town Council. In 1898 he married a daughter of Lieut.-General T. E. Webster. Ten years later he became master of St. John's and in 1910-12 was vice-chancellor of the University.

As master of St. John's, Scott showed how deeply the College had taken root in his affections by the labour which he bestowed on the College records. He had published in 1903 the second volume of the "College Admission Register" with biographical notes; and the accumulated work of his period as master was published so recently as 1931 in the third volume of the "Register". This work is rich in interest, and the biographical notes display the same human interest and sense of humour which characterised him at all times.

Scott was an honorary LL.D. of the University of St. Andrews, and in 1924 he received the honour of knighthood.

WE regret to announce the following deaths :

Dr. F. G. Crookshank, a well-known medical man and author of "The Mongol in Our Midst", on October 27, aged sixty years.

Mr. B. H. M. Hewett, engineer-in-charge of the Mersey Tunnel Scheme, who was also connected with the construction of the London Underground railways and with tunnelling projects in New York and Mexico, on November 14, aged fiftynine years.

Mr. John Lister, a well-known antiquary, a founder-member of the Halifax Antiquarian Society and for about thirty years its president, on October 12, aged eighty-six years.

Prof. Wilhelm Mielck, director of the Heligoland Biological Station, on October 5, aged fifty-four years.

Prof. L. R. Sutherland, emeritus professor of pathology of St. Andrews University College, Dundee, on November 6, aged seventy years. 